\title{
Minangkabau peace literature in West Sumatra: A critical discourse analysis
}

\section{Literatur perdamaian Minangkabau di Sumatra Barat: Analisis wacana kritis}

\author{
Wening Udasmoro \\ Department of Language and Literature, Faculty of Cultural Sciences, Universitas Gadjah Mada \\ Address: Jalan Nusantara No.1, Bulaksumur, Yogyakarta 55281 \\ E-mail: udasmoro@ugm.ac.id
}

\begin{abstract}
This research paper, focusing on the oral literature regarding peace in Minangkabau, West Sumatra, does not simply examine the meaning of oral literature, but also attempts to connect such literature with the social practices of its consumers. This has been carried out in an attempt to understand how, if peace literature is still a part of Minangkabau society, conflict and other acts of violence in the society can still occur. Three important questions must be answered: 1) How are works of oral literature regarding peace produced, consumed, and reproduced among the Minangkabau in Padang, West Sumatra? 2) Who is most involved in reproducing peace literature? 3) How is oral literature regarding peace related to social practices of peace? Critical discourse analysis can be a useful method for literary research. This can be attributed to the fact that works of literature are not simply fictional, but also social, meaning that they play an important role in bridging fact and fiction. The intent of this paper is to examine the connection between oral literature regarding peace and its discursive context through a strict investigation of the three layers of critical discourse analysis: linguistic practice, discursive practice, and social practice. The findings of this paper are that every generation creates their own definition of peace literature. Surau, family, schools, and media are the institutions that play important roles in producing peace literature. Young generations from different age categories consume and reproduce such literature based on their understanding of the discourses, despite the fact that they do not always follow the discourses in their social practices.
\end{abstract}

Keywords: Minangkabau; peace; critical; discourse; analysis

\begin{abstract}
Abstrak
Artikel yang memfokuskan diri pada sastra lisan masyarakat Minangkabau di Sumatra Barat ini tidak hanya bertujuan untuk meneliti makna dari sastra lisan tersebut, tetapi juga mencoba untuk menghubungkan antara sastra dengan praktik sosial dari para konsumennya. Tujuannya adalah untuk memahami jika sastra lisan mengenai perdamaian masih menjadi bagian dari masyarakat Minangkabau tetapi mengapa praktik-praktik kekerasan masih sering dilakukan. Ada tiga pertanyaan yang dikemukakan; pertama, bagaimana karya sastra lisan mengenai perdamaian diproduksi, dikonsumsi dan direproduksi oleh orang minangkabau di Padang Sumatra Barat? Kedua, siapa yang paling berperan dalam mereproduksi sastra perdamaian? Ketiga, bagamana sastra lisan perdamaian berkaitan dengan praktik-praktik sosial perdamaian? Critical Discourse Analysis digunakan sebagai metode dalam meneliti. Hal ini dilakukan karena sastra bukan hanya bersifat fiksional tetapi juga bermakna sosial yang berarti bahwa sastra dapat berperan penting dalam menghubungkan antara yang fiksi dan yang nyata. Tulisan ini bertujuan untuk menganalisis hubungan antara sastra lisan perdamaian dengan konteks diskursifnya melalui investigasi pada tiga tataran Critical Discourse Analysis, yakni tataran linguistik, tataran diskursif dan tataran praktik sosial. Temuan dari artikel ini adalah, pertama, setiap generasi menciptakan definisi mereka mengenai sastra perdamaian. Surau, keluarga, sekolah dan media adalah institusi yang peting dalam memproduksi sastra perdamaian. Generasi muda dari berbagai level usia mengkonsumsi dan mereproduksi sastra perdamaian tersebut sesuai dengan wacana yang disirkulasikan oleh institusi yang berbeda tersebut meskipun mereka tidak selalu patur pada wacana tersebut.
\end{abstract}

Kata kunci: Minangkabau; perdamaian; analisis; wacana; kritis

\section{Introduction}

A society is what it produces, consumes, and reproduces through its discourses. This sentence means that all societies continuously and regularly create discourses, and as a result the three processes are synchronous. Fairclough $(2001,2000)$ argues that discourse is shaped through the language used 
in social practice. Fairclough $(2001,1992)$ also holds that there are three important dimensions to discourse, and that they are all interrelated to the point that they are inseparable and form a single, united process (Maingueneau 2015 \& 2014). These three dimensions are, first, the object of analysisthe research object - meaning in this context written, spoken, and visual text (Fairclough 2001). The second dimension is the process in which text is consumed, i.e. through reading, listening, or watching. During this consumption process, consumers have their own references as forms of intertextuality and interdiscursivity. Intertextuality refers to other texts (particularly written texts, rules, or norms), whereas interdiscursivity refers to utterances made by other people. The third dimension is the sociohistorical conditions, named context by van Dijk (2009), which can explain the above processes. These socio-historical conditions have ideological aspects which explain people's social practices. As such, according to Fairclough there are three levels of analysis: description, which is often termed linguistic practice, interpretation, which is often termed discursive practice, and explanation, which is often termed social practice.

Much research has used critical discourse analysis, including in linguistics (Fairclough 2001, van Dijk 2009 \& 1997), psychology (Wetherell 1996), and religious studies (Wijsen 2013). Linguistics in particular is close to literature studies, as both fields use language as their main tools. However, the narrow gap between these fields has only rarely been bridged by using critical discourse analysis methods and perspectives. Researching literature in connection with a linguistic way of thinking, such as through the use of critical discourse analysis and methods, is quite important as such methods can examine not only literary texts but also their social contexts and ideological contents.

When a discourse is produced (at the first level), consciously or unconsciously it remains open to repetition and reproduction (the second level) which causes shifts in that discourse (Maingueneau $2010 \& 2005)$. When a new word emerges in a language and is more frequently used than its synonyms, there is a connection between this new word (as part of the dynamics of language) and the extralingual discourses - the social context (the third level) - which allow that word to spread (Van Dijk 2005). In an Indonesian-language context, in the decades before the 2000s, the word saya was more frequently used as a first person singular pronoun than the word $a k u$; the etymology of saya, which can be traced to the term sahaya 'servant', was considered to more clearly show humility. The word saya was also considered more formal, and thus used rigidly in formal communications. The widespread use of the term aku in place of saya beginning in the 2000s has shown the production, consumption, and reproduction of this word. The word $a k u$ is considered acceptable for use, particularly in verbal communications and even in formal situations, owing to the continued, wide-spread repetition of this word in society. The repetition of the word $a k u$ has occurred through the media (among others), particularly television and the social media which emerged in the late 2000s.

This language is produced by subjects, consumed by other subjects, and reproduced widely by various different subjects at the social level. Discourse, thus, is shaped by its temporal and spatial frame. In the context of critical discourse analysis, language is not simply a tool for communication. Rather, it is a social practice (Fairclough 2001 \& 1995, Van Dijk 1997). Another philosopher, Bourdieu (1994 $\& 1980$ ) also argues that language both constitutes and is constituted. This means that language is not only shaped by its society, but also shapes that society. He uses two constructionist phrases, structure structures and structure structuring, which indicate that there are always two processes which occur concurrently and in which language plays a role.

Various tools are used in critical discourse analysis, beginning from words (wording, alternative wording, re-wording), and sentences (at the syntactic and semantic level) (Fairclough 2001, Wijsen 2013). There is also the turn taking system, the interruption of a speaker's sentences by another person exhibiting his or her power. This can be attributed to critical discourse analysis considering language to be a social practice which is always connected to issues of power. A word which has become part of the jargon of society is connected with the entirety of that society's discourses. For instance, in the context of war and peace, the discourses of war presented by one group in society will also be implicit within that society's everyday discourses. The term crusade, for example, can 
be defined differently by different groups within society, depending on how the crusade discourse is socially given meaning. In this shared meaning, there are power functions which are positioned or position themselves as the ones able to legitimize the meaning of crusade.

Regarding discourses of conflict and peace, discourses of war are more frequently seen as political struggles owing to the involvement of certain economic, ideological, and social issues. However, discourses of war are not simply political discourses in which one group is in conflict with another. Rather, such discourses are located within structured societies, in the minds of community members, and in lengthy historical backgrounds. The Ambon conflict, for instance, which is always connected with a breakdown in relations between Christians and Muslims, is often said to have been caused by the socio-political situation following the fall of the New Order (Pamuji et al. 2008). It is frequently repeated among various parts of Ambonese society that Ambon had been, before the conflict, a peaceful society with good relations between Christians and Muslims. The Pela Gandong (familial ties without any blood connection) system was maintained in Ambon from generation to generation. However, upon further examination, discourses of conflict had already been present in day-to-day discourses, albeit in less severe forms. Many Ambonese responded to questions with statements such as "That was what usually happened when residents of two villages fought". There was a "usual" behavior in fighting. The term usual here indicates a production, consumption, and reproduction process behind the discourse of "fighting" which was already present within Ambonese society. This can also be connected to another piece of jargon, the description of the Ambonese as having "short fuses" (Krauss, Udasmoro \& Rahmawati 2014), meaning that they-particularly the men-are quick to anger. Problematically, when such stereotypes are continuously produced, consumed, and reproduced, they are considered normal, believed, and considered true and appropriate. Such views make community members believe that it is normal to commit violence. From these stereotypes, statements such as "He's Ambonese, but refined" emerge. Why must the term "but" be used to describe a "refined" Ambonese person? Such stereotypes are reproduced and preserved through numerous agents' everyday discourses.

Discourses of conflict and violence are prominent in literature. Conversely, it is difficult to find oral literature which explicitly deals with peace and is disseminated through whole narratives. Though modern technology has made it increasingly easy to virtually save data, it is nearly impossible to uncover narratives on oral traditions regarding peace in Indonesia. It is much easier to find oral traditions regarding conflict and war in the texts which are broadly disseminated through virtual media, be it institutional or individual. However, despite this lack of a significant number of oral traditions regarding peace, some works of peace literature have been found among the Minangkabau in Padang, West Sumatra. Although these stories are present as little more than dispersed wreckage in the face of comprehensive documentation of war literature, this research attempts to contextualize oral traditions regarding peace among the Minangkabau. This research assumes that, within Minangkabau society, fighting between teenagers and between students remains an issue.

Regarding oral literature, an expert on storytelling, Frank (2010), writes in his book Letting Stories Breathe that stories indicate the human capacity to articulate and discuss the problematic issues faced in life. Frank is uninterested in simply interpreting works of oral literature (such as fairy tales), as for him it is more important to explore the means through which oral literature creates dialogue in its society. Frank's idea is inspired by the writings of the Russian literary critic and avant-gardist in discourse studies, Bakhtin $(1994,1981,1986)$, who explains that the language used in stories is the product of conflicting social forces which offer constant reinterpretation; as a result, no story has a single meaning or interpretation (Winston 1998). The ability to explain linguistic operations and thus understand the connection between linguistic aspects, referential aspects (the references backgrounding language use), and social aspects (practices related to language use) is a strength of the critical discourse analysis method.

The issue discussed above, as connected to the position of oral literature within the context of broader social discourses, is the presence of oral literature regarding peace and harmony within society. 
However, one must ask why violence are still practiced by various groups, particularly students and teenagers. Several questions may be asked: first, how are works of oral literature regarding peace produced, consumed, and reproduced among the Minangkabau in Padang, West Sumatra? Second, who is most involved in reproducing peace literature? Third, how is oral literature regarding peace related to social practices of peace?

The goal of this research is to examine the connections between oral literature traditions and sociocultural discourses, namely the practice of peace discourses which are, on the one hand, widely distributed, but on the other hand overcome by social practices. This research is not intended to reinforce stereotypes which connect practices of violence with ethnicity, a mistaken perspective which is nonetheless often taken for granted.

This article uses critical discourse analysis (Fairclough $2001 \& 1992$ ) as its method. In this context, critical discourse analysis attempts to examine the text at the micro level (texts from oral literature) and macro level (discourse, namely the social and cultural practices of the Minangkabau in Padang, West Sumatra). The gap between these two, the mid-level of intertextuality and interdiscursivity, is an important part of the analysis.

In discourse analysis, literary texts are positioned as being part of a larger text, which is known as context (Van Dijk 2009). Van Dijk defines context as follows:

"Traditionally, context was defined as "objective" social variables (such as gender or class of speakers). It is not the social situation itself that influences the structures of text and talk, but rather the definition of the relevant properties of the communicative situation by the discourse participant."

Context here should be understood as the social context in which the discourses of oral literature regarding peace thrive. The society selected for research, the Minangkabau, is just one case of many throughout Indonesia which has discourses of peace. The Minangkabau were selected based on considerations of the presence of oral literature regarding peace within their society. The focus here is the availability and spread of discourses promoting peace and condemning violence which are consumed by this society as well as the means through which it reproduces discourses based on the aforementioned oral tradition.

Critical discourse analysis is not only interested in the content of data, nor does it attempt to simply find the meaning of works of oral literature. Rather, critical discourse analysis attempts to connect literary products with the context in which these texts exist (Maingueneau 2014). The interconnection between literature and society is realized through what is known as the order of discourse. This research is predominantly interested in exploring informants' textual consumption of the literary works consumed. This is intended to enable entry into the social practices related to their textual consumption. For this, the discourse products of the informants, their own statements about the literary works consumed, are the main tools of this research.

Data for this research was the oral literature consumption of informants, all of whom were between the ages of 13 and 26. This age range was a result of the selection of informants based on place of study: three in junior high school or equivalent, four in senior high school or equivalent, and four in university or equivalent. Interviews were focused on discovering informants' consumption of oral literature on peace as well as the context of their social practices in fighting/not fighting and involvement/lack of involvement in other forms of violence. Both aspects were examined and connected with other texts using intertextuality and interdiscursivity. The data was collected in April, May and June, 2016. There are 18 informants interviewed for this data.

Data for this research was context data (practices of violence and peace experienced in everyday life). Questions in the in-depth interviews used were intended to filter informants' opinions regarding peace perspectives as well as their opinions regarding whether or not peace and harmony were important discourses in the everyday lives of their communities and what experiences they have had with the discourses in their communities. 
Data analysis for this research used critical discourse analysis, which attempts to examine two different texts through their interconnections. The tools used were as follows: 1) Linguistic tools (words, sentences, and paragraphs), involving aspects of wording and alternative wording at the word level. Other levels included the sentence level and paragraph level, 2) At the discursive level, the intertextuality and the interdiscursivity, meaning the subjects or objects used as references by the individu were also used as tools of analysis. For instance, people might refer to the rules, the holy books, the parents and so on, and 3) Aspects of social and cultural practices related to ideology and other social were analyzed to see their connection with the linguistic tools above.

\section{Result and Discussion}

The narrated stories of fairy tales or myths can circulate in specific places and undergo various transformations (Utama 2017). Every generation consumes its own discourses, and no story consumed is ever the same, even though there is a tendency to voice certain stories more than others. For instance, among the people of West Sumatra, the story of Datuak Katumengguangan and Datuak Parpatiah Nan Sabatang, a work of oral literature regarding peace, was consumed by most informants (more than 65\%) of all ages (from age 13 to 26). However, how this story was told differed, and several versions were reproduced through different retellings.

In the context of critical discourse analysis, the accordance (or lack thereof) of a narrative with previously told versions is not an issue. As stated by Arthur Franck (2010), the most important point is not the meaning given to a story, but rather the story's relationship with its social context. As such, in the context of discourse, with a focus on textual consumption, the most important consideration is who retains stories from Minangkabau oral literature. From the eleven informants interviewed, an interesting pattern emerged regarding who continued to consume, remember, and reproduce these stories.

\section{Discourse transformation in oral literature: Production and consumption of oral literature}

This research has found a degradation in the consumption of oral tradition, with a clear connection between this degradation and age. Some of the informants who still studied at junior and senior high school (i.e. respondents between the ages of 13 and 18) no longer consumed oral literature with their families. Rather, they mostly consumed stories from television or school. In West Sumatra, particularly in Padang, the school curriculum includes a course titled Budaya Alam Minangkabau (BAM, meaning the Culture of Minangkabau Nature), which attempts to convey traditions of peace as part of its material. This generation, between the ages of 13 and 18, can be assumed to have been born in the television era. Almost all of the students interviewed were familiar with television shows and series.

Meanwhile, most informants aged between 19 and 22 stated that they had heard fairy tales and other stories from their families. Some of these informants were still studying in senior high school, while others were in the early semesters of university. In a family context, mothers had an important role as story tellers. Most informants (more than $80 \%$ ) stated that it was their mothers who had told those stories and fairy tales. Grandmothers also played an important role in transmitting Minangkabau oral tradition (fairy tales). Approaches to storytelling varied. Some parents told stories as their children were preparing to sleep, while others told stories as part of ordinary conversations. Meanwhile, among respondents aged 22 years or older - those who were studying at university or equivalentmuch fairy-tale telling was conducted in the surau (a sort of assembly building used for worship and religious instruction), with the Datuak (honored male members of the community) playing an important role in such retellings. Hendra (age 26) stated that he most often heard stories regarding the importance of peace and harmony from the datuk at the surau.

Table 1 show the process of production and consumption of the literary oral text by the different subjects. It is describe the shift of the producers of the texts. However, for the reproduction of the literary texts, most of them have the same idea about what to do and what should not do in the social practice. All of the argue that they should not fight against each other or creating enemies among them. In the transformation of the subject as a storyteller, different processes of institutionalization 
can be seen. A collective process of institutionalization, through the surau, was replaced by the family institution. Storytelling later shifted to media and school institutions. This transformation has occurred because of shifts in the social relations within Minangkabau society. When the surau no longer had the same authority as it had had, the family institution took control. However, the family, as an institution which had taken the role of storytelling from the surau, has not been maximal owing to the presence of television, which has a broader special and temporal scope. Television has served as a new medium for storytellers since the boom of this media in Indonesia. The presence of television, meanwhile, has led to schools having a greater role in storytelling, albeit one which is more local in scope (BAM, in Padang). The following figure illustrates the above-discussed shifts in narrating oral tradition.

Table 1.

Production and consumption of oral literature

\begin{tabular}{|c|c|c|c|}
\hline Production & Consumption & Description of Narration & Reproduction \\
\hline $\begin{array}{l}\text { Surau: } \\
\text { Mostly by } \\
\text { Datuak. }\end{array}$ & $\begin{array}{l}\text { Young people } \\
\text { aged } 22 \text { year } \\
\text { and more. }\end{array}$ & $\begin{array}{l}\text { Interviewer: Have you ever heard the story about peace } \\
\text { in Minang Society. } \\
\text { Hendra: Yes, the story about the Padang Sibusuk } \\
\text { Agreement. The conflict between Majapahit and } \\
\text { Minangkabau (Pagaruyung) Kingdom. There was an } \\
\text { agreement mediated by Koto Salak Kingdom. } \\
\text { Interviewer: Who told you the story? } \\
\text { Hendra: Datuak Bandaro, Mam. }\end{array}$ & $\begin{array}{l}\text { We don't have } \\
\text { to fight against } \\
\text { each other. }\end{array}$ \\
\hline $\begin{array}{l}\text { Families: } \\
\text { Mostly by } \\
\text { Mothers and } \\
\text { Grandmothers. }\end{array}$ & $\begin{array}{l}\text { Young people } \\
\text { aged } 19-21 \\
\text { years. }\end{array}$ & $\begin{array}{l}\text { Interviewer: Have you ever heard the story about peace } \\
\text { in West Sumatra? } \\
\text { Robi: Yes Mam } \\
\text { Interviewer: What story? } \\
\text { Robi: The story about Datuak Katumangguangan } \\
\text { Interviewer: What is the content of the story? } \\
\text { Robi: We don't have to have ennemies } \\
\text { Interviewer: Who told you the story? } \\
\text { Robi: My mother }\end{array}$ & $\begin{array}{l}\text { We don't } \\
\text { have to create } \\
\text { enemies at } \\
\text { school. }\end{array}$ \\
\hline $\begin{array}{l}\text { Media: } \\
\text { Television, } \\
\text { other Medias } \\
\text { and Schools. }\end{array}$ & $\begin{array}{l}\text { Young people } \\
\text { aged 13-18 } \\
\text { years. }\end{array}$ & $\begin{array}{l}\text { Interviewer: Have you ever heard the peace story in } \\
\text { Minangkabau? } \\
\text { Raihan: I know Mam. } \\
\text { Interviewer: What's story? } \\
\text { Raihan: Datuak Parpatiah, Mam. } \\
\text { Interviewwer: Who told you the story? } \\
\text { Raihan: From my primary school teacher. }\end{array}$ & $\begin{array}{l}\text { We don't have } \\
\text { to fight against } \\
\text { each other. }\end{array}$ \\
\hline
\end{tabular}

\section{Transformation from values to knowledge}

The media transformations which have caused a shift in the dissemination of oral traditions regarding peace have also had implications for the contents of such stories. It is clear that, when stories were told in in the surau, informants maintained clear memories of the stories conveyed. One informant could retell several of the stories heard from the datuk, an elder at the local surau who would always tell these stories to the youths who came to him for prayer recitations.

R: Who was fighting? Which group?

I: The Nagari of Koto Salak and the Nagari of Koto Gadang. So, when there'd be fighting between villages, in the nagari, there'd be bedug larangan. Bedug larangan, it means that the bedug (drum) could sound on its own. If it sounded on its own, something bad would happen. Usually people would be killed, caught by animals, or there'd be disease, or an enemy would attack. In the bedug, there's the head of a tiger. People there say that it's the skull of a tiger, and that tiger wanted to kill the king. But the tiger was killed. So the spirit of the tiger makes the noise, not the drum, really.

R: So if that happened, people would be scared, right?

I: Yes, they would be afraid. It's how it is. They say society and its leaders would be afraid. Cautious, when that happened. But there's none of that now. 
In critical discourse analysis, the order of discourse is an important part of explaining discourse. This is done by connecting three dimensions: linguistic practice, discursive practice, and social practice. Michel Foucault (1973) describes this as connecting the order of discourse. At the linguistic practice level, the alternative wording used is bedug larangan. This alternative wording, bedug larangan, gives rise to a number of utterances which appear almost chronological, namely: 1) "Bedug larangan, it means that the bedug (drum) could sound on its own"; 2) "If it sounded on its own, something bad would happen"; 3) "Usually people would be killed, caught by animals, or there had be disease, or an enemy would attack" and 4) "In the bedug, there is the head of a tiger".

The wording used above is connected with the second level, that of discursive practice, in which the informant uses specific references, such as in the sentence "They say society and its leaders would be careful". In this sentence, the text referred to is the discourse found in society and its leaders. As a result of this reference, certain social practices are manifested: fear and caution.

Based on the above discussion of these three dimensions, it is apparent that, in this story, the datuk codified certain values to ensure that the children would not fight. Mythologization was employed, and stories were infused with the imagination of myth. Such things as spirits, which are considered non-rational and unbelievable in modern society, were presented. This mythologization brought with it something else: a fear of doing something forbidden by the myth. Specific values were conveyed through this story, and, as this story was often repeated - every evening, when the children were praying at the surau - these values were embodied. To borrow from Butler (1997 \& 1990), there was a process of performativity, of repeating something until it had unconsciously become part of the children's mindset. Such narration could be found among most informants who were over 22 years of age.

The reason this has been found among those aged 22 years and older cannot be divorced from the social context. These discourses were present in the beginning of the 1990s and at the end of the 1980s, a time when the role of the collective was still important among different Indonesian peoples, including the Minangkabau. Myths still spread freely within society. In film, for instance, myths were presented as being brought to life and consumed jointly by society. The films starring Suzana as woman spirits were commonly found in everyday discourses. In various regions, including Java which had already undergone greater modernization than other rural areas, myths still had a presence in everyday life (Geertz 1976). As such, it is not strange that a university student could still remember his childhood and how myths had been used to frighten him and thus convey educational messages when discussing the messages of peace and harmony he had received (Udasmoro 2012).

Meanwhile, a different pattern could be seen among those who were raised during a similar period of time, the students in senior high school or the early years of university-youths aged 19 to 22 . Most of the respondents in this group stated that it was not a datuk who told them stories, but rather their parents - particularly their mothers. In this context, there is a similarity in the storytelling patterns used. Children listened to the content of these stories before they fell asleep. As their parents told them fairy tales, they listened and received messages regarding the importance of avoiding fights and ensuring harmony with their neighbours and friends. Values were conveyed to these informants every evening, as part of their everyday childhood routines. The shift from the collective institution of the surau to the family institution shows the role of the family in educating children. Family, or more precisely in this case mothers, played a significant role in educating children.

This begs the question: why mothers? It cannot be said that this is simply a manifestation of the mother construct, what Julia Suryakusuma (2011) terms State Ibuism, in which the State shaped mothers to be pillars of the domestic sphere and moral compasses for their families. Rather, this discourse can be considered part of a more broadly distributed discourse, one which was promoted not only by the government's Family Welfare Education (Pendidikan Kesejahteraan Keluarga, PKK) program, but also by the mindset spread through State and religion. In the 1980s and 1990s, the New Order government succeeded in convincing Indonesian society, including those living outside of Java, about the important role of mothers in families. As such, similarly with the collective role discussed above, there were values being repeated and thus memorized by the children who consumed oral literature. 
This differs significantly with the experiences of students at junior high school and the early years of senior high school, most of whom no longer heard stories at the surau or from their parents (mothers). These storytellers had been replaced by schools. In terms of period, this shift occurred mostly during the 2000s, as the informants in this category were all between the ages of 13 and 18 at the time of the interviews. Schools have had an important role in educating children through narratives and stories which are intended to promote character education and to preserve oral literary traditions. In Padang, West Sumatra, the school course the Culture of Minangkabau Nature (Budaya Alam Minangkabau, or $B A M$ ) has been important for the institutionalization of Minangkabau oral traditions.

The involvement of schools is an important point in the narration of oral tradition, which has begun to transform into written literature. The presence at schools of written literary traditions regarding peace can be considered to be positive, as it shows concern for the fact that oral traditions have begun to disappear as reproduction, both at the surau by the datuk and at home by parents, has become increasingly uncommon. The presence of television culture, which overwhelms children's discourses in their everyday lives, can be attributed for the emergence of schools as reinvigorators of oral tradition. However, the issue is that schools have not taken up one function previously fulfilled by the datuk or parents in their retellings. In school-based reproduction of oral literature, story contents are simply presented as knowledge, as with other school subjects, and as such there has been a shift from embedded values to knowledge. This can be seen, for instance, from the fact that most informants had entirely forgotten the stories they had learned. These stories and their values had no opportunity to become embedded, because, unlike at the surau or in the family, they were not regularly repeated.

\section{The revival of tradition}

In politics, there has been a call for returning to or reviving traditions which have begun to disappear. This has been realized by one of the institutions in Minangkabau society: schools, specifically elementary schools which offer courses in Minangkabau culture, or BAM. Almost all informants interviewed explained that they had learned oral traditions related to peace from this course, which is compulsory for all students in Padang.

R: Grade 7, that's the same as Grade 1 [of Junior High School], right? So have you ever known those stories? In elementary school, did you learn about Datuak Parpatiah Nan Sabatang and Datuak Katumanngguangan?

I: I did.

R: What is the Batu Batikam?

I: A historical artefact.

R: Do you know the story of Datuak Parpatiah Nan Sabatang and Datuak Katumanggungan nan Batu Batikam. Do you?

I: I can not remember.

R: Did you once know the story?

I: I did.

$\mathrm{R}$ : When?

I: In elementary school.

$\mathrm{R}$ : During which lesson?

I: BAM.

R: Did your teacher not tell you how the story went?

I: My teacher did.

At the level of linguistic practice, the informant knows of the story. He also knows that his teacher at school told him this story. There is awareness that the story had been explained in elementary school. However, at the discursive practice level, the student only answered because he had received information from the researcher. In terms of social practice, the student has no memory of the story.

As such, the student shows awareness of this story being told. School is recognized as playing a role in reviving oral traditions related to peace. There is an institutionalization process at play in which traditions which have been disappearing in the family are revived elsewhere. 
There has been a shift here, one related to oral traditions-particularly oral traditions regarding peace. Such oral traditions have, over time, been disappearing from the domestic sphere and thus been revived in the public sphere by the State institution. This has been codified in the school course $B A M$, and been accompanied with a shift in approaches to storytelling. Previously, storytelling had been a pleasure, an enjoyable activity, whereas presently it has become an institutional alternative. Oral traditions had been consumed collectively to explain phenomena found within that collective have transformed into a required understanding.

Although a similar pattern is apparent - the institutionalization of stories through schools - the revival model differs. In West Sumatra there is a very specific effort, one of re-invention of tradition, being sponsored by the provincial government and promoted through $B A M$.

\section{Oral traditions of peace and practices of violence}

Research into the informants' responses indicate that a pattern in which the consumption of parents' words of wisdom influences respondents to not perpetrate violence.

I: Because from before I have never fought.

R: Did your parents give you any words of wisdom to forbid you from fighting?

I: Yes, they did.

$\mathrm{R}$ : What did your parents usually tell you?

I: Well, it was, "Have to watch the family's good name". "You may not fight, get into trouble and get your parents involved."

In the above example, linguistic practice can be seen in the sentences "Have to watch the family's good name." and "You may not fight, get into trouble and get your parents involved." The reference, or the discursive practice, used was the petuah (advice) given by parents. At the social practice level was the sentence "Because from before I've never fought." This indicates a circular pattern, in which the informant has not fought because he has consumed the petuah from his parents. The ideology presented by parents in this petuah is one regarding the family's good name, as well as the parents' unwillingness to become involved in their child's fighting.

One other pattern of discourse shows a significant difference with the above. As shown below, there is a connection between the absence of efforts to reproduce oral literature regarding peace and harmony which contributes to social practices of violence. The following quote comes from an interview with Robi, a vocational school student.

R: Oh, okay. Did you ever hear fairy tales, folktales, about peace, about living in harmony? Did you ever hear those?

I: No.

R: Never, then. Okay, and on television, did you ever see tales of peace? Or movies? Do you remember any?

I: There was something, but I forget the title.

R: You forget, but you did? Okay, good. And while you've been in school, have you ever fought with anyone?

I: Yes.

R: You did? Where was that?

I: In elementary school.

R: In elementary school? Only in elementary school?

I: In elementary school and junior high school?

R: In junior high school, too? And now? Never? What happened in elementary school?

I: Because of misunderstandings.

The above utterance shows, at the linguistic practice level, that the informant has explained one memory which he remembers and one which he does not remember. First, he does not remember the 
stories about peace, here realized through the use of the terms never and forget. Meanwhile, at the discursive practice level, a lack of consumption of texts regarding peace and harmony can be seen. There is one reference, to television, but the consumption of texts through television is not present at the cognitive level. At the social practice level, it is clear that the informant states that he "fought" in elementary school because of "misunderstandings".

It cannot be said that persons who heard oral traditions regarding peace and harmony do not subsequently fight. One informant offers an example of how someone can consume oral tradition but still fight for different reasons. Specific answers must be explored in greater depth to understand consumption patterns of oral literature. Although these are not an such issues of oral tradition, in the form of fairy tales and other stories, it is still important as it is connected with the consumption of oral literature and its role in promoting peace and harmony.

There is an interesting contribution from the father, which differs significantly from the mother's role in embedding peace values within children. The following statement is from one informant.

I: Playing football, see. And there's another thing, too. Once in a while, they, well, it's senior high school students, they get really emotional. Someone scrapes someone with a motorcycle and they're fighting. Doesn't matter what the issue is. Sometimes, if someone's girlfriend is bothered by someone from another school, I'll also join them again.

R: Do your parents know that you often fight, Aldi?

I: Yes.

R: What kind of advice do they give you?

I: Father says, "Fighting, one on one, is okay. But if you gang up on someone, I'll beat you." The important thing is that I don't destroy my body with drugs or what-have-you.

At the linguistic practice level, some specific wordings were used by the informants, such as "well, it's senior high school students, they get really emotional". This linguistic practice indicates a tolerance for senior high students to exhibit anger. Another sentence, "Someone scrapes someone with a motorcycle and they're fighting", indicates that such anger is realized even for small incidents. As stated by the informant, it "Doesn't matter what the issue is".

What is most interesting about this utterance, however, is the fact that the father only plays a minor role in the storytelling process within the family. Some informants indicated that their fathers were involved as storytellers. However, these fathers were involved not in narrating peace, but rather in narrating violence. Here, a sentence from the informant's father is used as a reference in discursive practice: "Fighting, one on one, is okay. But if you gang up on someone, I'll beat you." There is a reproduction of violence, and this violence is produced, consumed, and reproduced within the social practice level; the informant is a student who frequently fights, as indicated by the sentence "I'll also join them again". The informant's social practice of fighting, as indicated by the term "again", is one which is often repeated. As such, there is a relevant connection between linguistic practice, discursive practice and social practice, a circular pattern in which violence is continuously reproduced because it is tolerated by figures respected by the informant.

In this article, which examined Minangkabau oral literature regarding peace from a critical discourse analysis perspective, several important findings have been made. First, these works of oral literature have been transformed over generations. Different generations have defined oral tradition regarding peace in different ways. For older youths, fairy tales and other stories are still used to prevent practices of violence. Connotative meanings are put forth. Meanwhile, younger youths no longer use myths. They tend to rely on non-mythical discourses, such as direct petuah, or denotative meaning.

The second transformation in the reproduction of peace through stories is institutional in nature. There has been a shift in storytelling subjects, from the surau in the villages, with the storytellers being the datuk, to parents (particularly mothers), and then to visual culture through television, the 
internet, and social media. Schools have also played a part, as they have been positioned as "the last bastions of culture" in the face of minimal parental involvement and the presence of a disorderly and (it is believed) highly dangerous visual culture. The storytelling medium has also seen a shift, from orality to the written word, through school institution involvement.

Third, there has been a transformation in the content being conveyed. There has been a shift from value to knowledge. Substantive issues of oral literature, with their messages of peace, were presented by the Datuk in the surau and the mothers at home. These issues took the form of messages for harmonious living, and these values were so emphasized through repetition and performativity that they became embedded within the youth. Schools, meanwhile, can be said to have failed to develop oral tradition as a value. Rather, they have tended to use such stories as knowledge to be memorized, and, as a result, stories and the values they contain are frequently forgotten by the youth.

Discourses of peace have continued to be reproduced, despite discourses in the form of fairy tales having seen degradation in their narration. Only a few stories regarding peace were remembered by informants, and most only remembered one or two such stories. Interestingly, the narratives in these stories have different profiles as viewed by informants. All informants had their own understandings of harmony, of who produces harmony, and from whom these stories were received. Fairy tales that were previously reproduced as myths have been, over time, replaced by narratives which are not connected at all with mythology. Only a few informants, particularly those over the age of 23, still reproduced stories as myths. Younger informants, particularly those who were still teenagers, tended to consume stories produced by television, which depict more contemporary events. There is a difference in the positioning of the real and imaginary in the discourses consumed by informants.

\section{Conclusion}

The reproduction of peace literature is gendered. Fathers and mothers have different roles in the reproduction of oral literature regarding peace. Masculinity and femininity shape divergent concepts of peace. From informants' discourses, it was clear that mothers had played a significant role in reproducing oral tradition regarding peace. Most of the informants interviewed had heard fairy tales from their mothers. Fathers' roles were more limited, and at times was not present at all. When fathers did play a role, however, they used traditions of violence to explain masculine power and relations. A broader masculine regime reinforced and sowed the seeds of a culture of violence, such as through the story of the older as a "hero" who fought for and was respected by his younger sibling. Furthermore, older classmates and school alumni served as agents provocateurs who reproduced traditions of violence in schools.

Oral literature regarding peace, which in this case refers to fairy tales and stories, has a nonlinear connection with the social practice of peace. It cannot be said that persons who have consumed oral literature regarding peace will indeed practice non-violence. Rather, persons who consume such literature within a context of close parental supervision tend to avoid committing acts of violence. Meanwhile, persons who have not consumed oral literature regarding peace almost always commit acts of violence more frequently; they lack the value and knowledge background necessary for recognizing the importance of maintaining peace and harmony.

Oral literature in the form of petuah has the same social effect as fairy tales. The role of the subject, as the storyteller, is paramount in reinforcing youths' cognitive understanding of the importance of avoiding (or not avoiding) acts of violence. The young generations follow the discourses created by the different institutions but not always practice it in their everyday life.

\section{References}

Aldi [Personal communication].

Bakhtin M (1986) Speech Genres and Other Late Essays. Trans. Vern W. McGee. Austin, TX: University of Texas Press. 
Bakhtin M \& Holquist M (1981) The Dialogic Imagination: Four Essays. Austin. TX: University of Texas Press.

Bakhtin M \& Morris P (1994) The Bakhtin Reader. Oxford: Oxford University Press.

Bourdieu P (1980) Questions de Sociologie. Paris: Les Éditions de Minuit.

Bourdieu P (1994) The Field of Cultural Production: Essays on Art and Literature. New York. NY: Columbia University Press.

Butler J (1990) Gender Trouble: Feminism and the Subversion of Identity. New York and London: Routledge.

Butler J (1997) Excitable Speech: The Politics of the Performative. New York and London: Routledge. Fairclough N (1992) Discourse and social change. Cambridge, MA: Polity Press.

Fairclough N (1995) Critical Discourse Analysis: Critical Study of Language. New York: Longman.

Fairclough N (2000) Discourse, social theory and social research: The discourse of welfare reform. Journal of Sociolinguistics 4:163-195.

Fairclough N (2001) Language and Power. New York: Taylor \& Francis.

Frank AW (2010) Letting the Stories Breathe: A Socio Narratology. Chicago, IL: University of Chicago Press.

Geertz C (1976) The Religion of Java. Chicago: The University of Chicago Press.

Hendra [Personal communication].

Krauss J, Udasmoro W, \& Rahmawati A (2014) Gender dimensions in social conflict and peace building, Ambon case. Working Paper, 2.

Maingueneau D (2005) Pragmatique pour le Discourse Litteraire. Paris: Armand Collin.

Maingueneau D (2010) Au dela des Oeuvres: Les Voies de l"analyse du Discours Litteraire.

Maingueneau D (2014) Discours et Analyse du Discours: Paris: Armand Collin.

Maingueneau D (2015) Manuel de Linguistique pour les Textes Litteraires. Paris: Armand Collin.

Pamuji M, Nanang, Horiba, Miqdad, Gogali, \& Sipasulta L (2008) Success Story Mekanisme Komunitas dalam Penanganan dan Pencegahan Konflik: Studi kasus di Desa Wayame (Ambon) dan Desa Tangkura (Poso). Jakarta: FES.

Robi [Personal communication].

Suryakusuma J (2011) State Ibuism. Jakarta: Komunitas BAMbu.

Udasmoro W (2012) Spiritualitas Warga Merapi: Discourse Ruang dan Waktu dalam Menghadapi Bencana. In: Merapi dalam Kajian Multidisiplin. Yogyakarta: Graduate School Universitas Gadjah Mada, 135-154.

Utama I (2017) Tari Minangkabau: Dari Pencak dan Pamenan ke Tari Persembahan. Kuala Lumpur: Penerbit Universiti Malaya.

Van Dijk T (1985) Handbook of Discourse Analsysis. London: Academic Press.

Van Dijk T (1997) Discourse as Structure and Process, London: Sage Publication.

Van Dijk T (2009) Society and discourse: How social context influences text and talk. Cambridge, NY: Cambridge University Press.

Wetherell M (1996) Group conflict and the social psychology of racism. In: M. Wetherell (ed.), Identities, groups and social issues. London: Sage.

Winston J (1998) Drama, narrative and moral education: Exploring traditional tales in the primary years. Washington D.C.: Falmer Press.

Wijsen F (2013) Religious discourse, social cohesion and conflict: Studying Muslim-Christian Relations. Bern: Peter Lang. 